\title{
EFFICIENCY OF IMPREGNATION WITH SALT SOLUTIONS IN THE RESISTANCE OF Corymbia torelliana AND Eucalyptus cloeziana WOODS TO FUNGUS Postia placenta
}

\author{
Pedro Lício Loiola ${ }^{*}$, Juarez Benigno Paes², Raquel Marchesan ${ }^{3}$, Graziela Baptista Vidaurre², Ricardo Jorge \\ Klitzke $^{1}$ \\ ${ }^{1}$ Universidade Federal do Paraná, Programa de Pós-Graduação em Engenharia Florestal, Curitiba, Paraná, Brasil - pedrlicio@ @otmail.com, \\ jkklitzke@gmail.com \\ ${ }^{2}$ Universidade Federal do Espírito Santo, Programa de Pós-Graduação em Ciências Florestais, Jeronimo Monteiro, Espírito Santo, Brasil - \\ jbp2@uol.com.br, grazividaurre@gmail.com \\ ${ }^{3}$ Universidade Federal do Tocantins, Curso de Engenharia Florestal, Gurupi, Tocantins, Brasil - raquelmarchesan@uft.edu.br
}

Received for publication: 17/12/2018 - Accepted for publication: 17/05/2019

\begin{abstract}
Resumo
Eficiência da impregnação com soluções salinas na resistência das madeiras de Corymbia torelliana e Eucalyptus cloeziana a fungo deteriorador de madeira Postia placenta. A pesquisa teve como objetivo avaliar a eficiência de soluções salinas (cloreto de sódio, cloreto de lítio, carbonato de sódio, sulfato de magnésio, sulfato de zinco e sulfato de cobre II) impregnadas nas madeiras de Corymbia torelliana e Eucalyptus cloeziana na resistência biológica ao fungo de podridão parda (Postia placenta) em condições de laboratório. De cada espécie foram retiradas amostras de $2,0 \times 2,0 \times 3,0 \mathrm{~cm}$ (tangencial x radial x longitudinal), ao longo dos pranchões obtidos na região do cerne no sentido base-topo. As amostras foram impregnadas com soluções a $5 \%$ de concentração e submetidas durante 16 semanas à ação do fungo Postia placenta em condições de laboratório. A madeira de Eucalyptus cloeziana foi mais resistente à deterioração que a de Corymbia torelliana, tanto impregnada com soluções salinas quanto não impregnada (natural). Os tratamentos com soluções salinas foram satisfatórios quanto à resistência da madeira à degradação, servindo como um parâmetro para a avaliação da madeira ao fungo xilófago testado.

Palavras chaves: Tratamento da madeira, fungo de podridão parda, biodeterioração.
\end{abstract}

\begin{abstract}
The research aimed to evaluate the efficiency of salt solutions (sodium chloride, lithium chloride, sodium carbonate, magnesium sulfate, zinc sulfate, and copper II sulfate) impregnated in Corymbia torelliana and Eucalyptus cloeziana woods on biological resistance to brown rot (Postia placenta) fungus under laboratory conditions. Wood test samples of $2.0 \times 2.0 \times 3.0 \mathrm{~cm}$ (tangential x radial x longitudinal) from each species were taken of the planks obtained in the heartwood region on base-top direction. The samples were impregnated with 5\% concentration of solutions and submitted for 16 weeks to the $P$. placenta fungus under laboratory conditions. The wood of E. cloeziana was more resistant to decay than C. torelliana, both impregnated with salt solutions as not impregnated. The treatments with saline solutions were satisfactory as regards resistance of wood degradation, and may be used as a parameter for the evaluation of the wood, the xylophagous tested fungus.
\end{abstract}

Keywords: Wood treatment, brown rot fungus, biodeterioration.

\section{INTRODUCTION}

Wood is a building material from renewable forest resources and, being a material of biological origin, its service request is subject to the effects of the weather and changes in environmental conditions and even those of recognized natural durability are prone to attack of xylophagous organisms. According to Araújo; Paes (2018), wood resistance to deterioration is the inherent ability of the species to withstand the action of deteriorating agents, including biological, physical and chemical agents.

Knowledge of the natural resistance is important to recommend the most appropriate use, saving unnecessary expenses with the replacement of parts and reducing the impacts to the environment (PAES et al., 2008). To evaluate the natural biological resistance of wood, accelerated laboratory tests are an alternative in which wood samples are exposed to xylophagous fungi that cause white or brown rot.

The xylophagous fungi are the organisms responsible for the greater losses caused to the wood intended for use in solid products. Among the fungi responsible for the rotting of wood, the basidiomycetes class stands out, in which are found the fungi responsible for white and brown rot, having the Postia placenta among them. 
They decompose the polysaccharides of the cell wall, and the attacked wood has a residual brownish coloration (RINGMAN et al., 2015).

Due to the increasing demand for use of Eucalyptus woods, which demonstrably have high dimensional instability (PAES et al., 2015), some new techniques for improving the characteristics of wood as your hygroscopicity, and which have characteristics fungicides (PAES et al., 2013). However, due to the environmental pressures, the development of products of wood preservatives that are less harmful to the environment, when compared to traditional and effective products, which are made up of base metals such as copper, chromium, arsenic, boron and amines, which are not corrosive to metals (PAES et al., 2017), in order to meet, more broadly, the timber market (MARCHESAN, et al. 2015).

The purpose of this research was to evaluate the efficiency of saline solutions (sodium chloride, lithium chloride, sodium carbonate, magnesium sulfate, zinc sulfate and copper sulfate - II) impregnated in the Corymbia torelliana and Eucalyptus cloeziana woods on biological resistance to brown rot fungus (Postia placenta) under laboratory conditions.

\section{MATERIAL AND METHODS}

\section{Obtaining wood, production and impregnation of samples}

The woods used in the research were Corymbia torelliana and Eucalyptus cloeziana that were in the form of planks, coming from forest plantations with 15 years of age, located in the region of Vale do Rio Doce in the state of Minas Gerais. The wood of Pinus sp., obtained in local businesses, Jerônimo Monteiro, state of Espírito Santo, Brazil, was also used as control.

From each eucalypts species and pinus wood, samples of $2.0 \times 2.0 \times 3.0 \mathrm{~cm}$ (tangential $\times$ radial $\mathrm{x}$ longitudinal) were taken, over the wooden planks obtained in the heartwood region on base-top direction. A total of 112 test samples free of defects such as nodes and gum resins, more the control, were used.

The samples were dried in an air circulated kiln, maintained at $103 \pm 2{ }^{\circ} \mathrm{C}$, until constant mass, weighed in scale with an accuracy of $0.01 \mathrm{~g}$. The dry samples were impregnated with solutions at $5 \%$ concentration (mass/volume) of the grade of salt purity (sodium chloride, lithium chloride, sodium carbonate, magnesium sulfate, zinc sulfate and copper (II) sulfate) in a desiccator under intermittent vacuum, during 96 hours. The saline solution absorption $(\%)$ by woods was determinate and dry salt retention $\left(\mathrm{kg} \mathrm{m}^{-3}\right.$ of wood) was calculated according to American Society for Testing and Materials - ASTM D-1413 (2008).

The wood of the species studied had basic density of $0,55 \mathrm{~g} \mathrm{~cm}^{-3}$ (C. torelliana) and $0.63 \mathrm{~g} \mathrm{~cm}^{-3}(E$. cloeziana), as reported by Paes et al. (2015) in studies to examine the effect of saline solutions tested on wood dimensional stability.

\section{Determination of the biological resistance of wood}

The determination of the biological resistance of Corymbia torelliana and Eucalyptus cloeziana woods was carried out by means of a laboratory accelerated rotting test, as described by the American Society for Testing and Materials - ASTM D-1413 (2008).

The assay took place in $600 \mathrm{~mL}$ bottles, filled with $300 \mathrm{~g}$ of soil with $6.87 \mathrm{pH}$ and water retention capacity of $138.76 \%$, as designated by ASTM D-1413 (2008). The soil of each bottle was moistened, according to water retention capacity and two seeder strips of Pinus sp. were added in each bottle. The bottles were sterilized at 121 ${ }^{\circ} \mathrm{C}, 1.1 \mathrm{kPa}$, for 30 minutes.

After cooling of the bottles, fragments were obtained from pure cultures of the fungus Postia placenta (Fr.) M.J. Larsen \& Lombard (Mad 698) from the Forest Products Laboratory, United State Department of Agriculture, and put on the seeder strips. After the development of the fungus in the Pinus sp. feeders and colonization in the soil, the test samples were added at the rate of two samples per bottle and eight replicates for each forest species and saline solution, including the control (Pinus sp. wood samples).

The assay was kept in an acclimatized room $\left(28 \pm 2{ }^{\circ} \mathrm{C}\right.$ and $75 \pm 5 \%$ relative humidity) for 16 weeks. After this period, the samples were dried under the same conditions prior to the assay and the mass loss was calculated as described in ASTM D-2017 (2008). The exposure time (16 weeks) was enough that samples of Pinus sp. wood, of same dimension, had mass loss $\geq 50 \%$. This shows that the culture of the fungus was vigorous, and the exposure time sufficient to server deterioration of wood samples.

\section{Statistical analysis of results}

The saline solution absorption (\%) by woods and dry salt retention $\left(\mathrm{kg} \mathrm{m}^{-3}\right.$ of wood) were evaluated by descriptive statistic and the arithmetical average and coefficient of variation were assessed. For analysis of the wood biologic resistance, a completely randomized design was used in a factorial arrangement, containing the 
factors of forest species (two levels), treated and non-treated and saline solutions (seven levels), with eight replicates per treatment, totaling 112 samples, more Pinus sp. wood samples used as control.

To enable statistical analysis, data on percentage of mass loss were transformed into arcsen [square root (mass loss / 100)], as suggested by Stell; Torrie (1980). Such transformation was necessary to allow the homoscedasticity of the variances. For the factors and interactions detected as significant by the $F$ test $(p<0.05)$, the Tukey test was used $(\mathrm{p}<0.05)$. The normality of the data was verified by the Lilliefors test and the homogeneity of the variances by the Cochran test.

\section{RESULTS}

The time of 96 hours under vacuum was not enough for the wood test samples stay completely saturated, as postulated by Siau (1995). But, reached moisture contents were more than fiber saturation point (FSP), on the basis of the saline solution absorption (Table 1). The dry salt retentions ( $\mathrm{kg} \mathrm{m}^{-3}$ of wood) varied little among the saline solutions used, with maximum values of $3.04 \mathrm{~kg} \mathrm{~m}^{-3}$ (Corymbia torelliana) and 2.94 (Eucalyptus cloeziana), Table 1. The differences in retention and absorption values of the saline solutions are related to wood density $(0.55$ $\mathrm{g} \mathrm{cm}^{-3}$ - C. torelliana and $0.63 \mathrm{~g} \mathrm{~cm}^{-3}-$ E. cloeziana). Thus, highest densities promoting more absorptions by fibers and, consequently, greater salt retention.

Table 1. Saline solution absorption and dry salt retention in the Corymbia torelliana and Eucalyptus cloeziana woods for different salt solutions evaluated.

Tabela 1. Absorção de solução salina e retenção de sal seco nas madeiras de Corymbia torelliana e Eucalyptus cloeziana para as diferentes soluções salinas avaliadas.

\begin{tabular}{|c|c|c|c|c|}
\hline \multirow[b]{2}{*}{ Treatments } & \multicolumn{2}{|c|}{ Saline solution absorption (\%) } & \multicolumn{2}{|c|}{ Dry salt retention $\left(\mathrm{kg} \mathrm{m}^{-3}\right)$} \\
\hline & $\begin{array}{l}\text { Corymbia } \\
\text { torelliana }\end{array}$ & $\begin{array}{c}\text { Eucalyptus } \\
\text { cloeziana }\end{array}$ & $\begin{array}{l}\text { Corymbia } \\
\text { torelliana }\end{array}$ & $\begin{array}{c}\text { Eucalyptus } \\
\text { cloeziana }\end{array}$ \\
\hline Non-treated wood* & $\begin{array}{l}53,92 \\
(3,95)\end{array}$ & $\begin{array}{l}76,29 \\
(22,56)\end{array}$ & ------------ & ------------- \\
\hline Sodium chloride & $\begin{array}{l}44,89 \\
(15,30)\end{array}$ & $\begin{array}{l}62,08 \\
(18,49)\end{array}$ & $\begin{array}{l}13,37 \\
(22,30)\end{array}$ & $\begin{array}{l}22,46 \\
(19,53)\end{array}$ \\
\hline Lithium chloride & $\begin{array}{l}42,01 \\
(3,84)\end{array}$ & $\begin{array}{l}69,30 \\
(14,94)\end{array}$ & $\begin{array}{l}12,21 \\
(5,93)\end{array}$ & $\begin{array}{l}25,40 \\
(14,36)\end{array}$ \\
\hline Sodium carbonate & $\begin{array}{l}43,41 \\
(20,11)\end{array}$ & $\begin{array}{l}64,11 \\
(19,34)\end{array}$ & $\begin{array}{l}12,62 \\
(22,08)\end{array}$ & $\begin{array}{l}23,93 \\
(19,30)\end{array}$ \\
\hline Magnesium sulfate & $\begin{array}{l}49,15 \\
(19,32)\end{array}$ & $\begin{array}{l}67,60 \\
(11,35)\end{array}$ & $\begin{array}{l}14,47 \\
(25,03)\end{array}$ & $\begin{array}{l}23,93 \\
(15,12)\end{array}$ \\
\hline Zinc sulfate & $\begin{array}{l}48,59 \\
(18,71)\end{array}$ & $\begin{array}{l}72,59 \\
(20,43)\end{array}$ & $\begin{array}{l}14,14 \\
(20,54)\end{array}$ & $\begin{array}{l}25,02 \\
(15,59)\end{array}$ \\
\hline Copper (II) sulfate & $\begin{array}{l}50,28 \\
(21,26) \\
\end{array}$ & $\begin{array}{l}63,21 \\
(10,51) \\
\end{array}$ & $\begin{array}{l}15,23 \\
(27,41)\end{array}$ & $\begin{array}{l}22,53 \\
(12,54) \\
\end{array}$ \\
\hline
\end{tabular}

* Water absorption (\%); Values between parentheses are the coefficient of variation.

The analysis of variance of the mass loss data (\%) caused by the degradation by xylophagous fungus tested, for the different saline solutions impregnated in the woods of Corymbia torelliana and Eucalyptus cloeziana showed significant results by the F test, for the treatments, forest species and for the interaction among these factors. The effect of the interaction was outspread and averages compared (Table 2).

Table 2. Mass loss of Corymbia torelliana and Eucalyptus cloeziana woods for different salt solutions evaluated. Tabela 2. Perda de massa das madeiras de Corymbia torelliana e Eucalyptus cloeziana para as diferentes soluções salinas avaliadas. 


\begin{tabular}{lcc}
\hline \multirow{2}{*}{ Treatments } & \multicolumn{2}{c}{ Wood specie /Mass loss (\%) } \\
\cline { 2 - 3 } & Corymbia torelliana & Eucalyptus cloeziana \\
\hline \multirow{2}{*}{ Non-treated wood } & $24,03 \mathrm{aA}$ & $2,16 \mathrm{bAB}$ \\
& $(19,72 \%)$ & $(15,36 \%)$ \\
Sodium chloride & $5,66 \mathrm{aB}$ & $4,24 \mathrm{aAB}$ \\
& $(13,33 \%)$ & $(11,72 \%)$ \\
\hline Lithium chloride & $6,76 \mathrm{aB}$ & $5,33 \mathrm{aA}$ \\
& $(14,17 \%)$ & $(12,90 \%)$ \\
\hline Sodium carbonate & $5,43 \mathrm{aB}$ & $4,66 \mathrm{aA}$ \\
& $(13,09 \%)$ & $(13,60 \%)$ \\
\hline \multirow{2}{*}{ Magnesium sulfate } & $3,64 \mathrm{aB}$ & $1,79 \mathrm{aAB}$ \\
& $(24,97 \%)$ & $(25,59 \%)$ \\
\hline \multirow{2}{*}{ Zinc sulfate } & $5,92 \mathrm{aB}$ & $0,79 \mathrm{bB}$ \\
& $(20,14 \%)$ & $(18,53 \%)$ \\
\hline \multirow{2}{*}{ Copper (II) sulfate } & $5,24 \mathrm{aB}$ & $2,94 \mathrm{aAB}$ \\
\end{tabular}

Wood specie (A) $123,53^{* *} \quad$ Treatment (B) $34,68^{* *} \quad$ Interaction A x B 41,16**

** F, p < 0.01. Average values followed by the same capital letter, vertically, or lowercase, horizontally, in each section, do not differ (Tukey, $\mathrm{p}>0.05)$. Values between parentheses correspond to the coefficient of variation.

A better effect of the saline solutions in the improvement of the resistance of the wood of $C$. torelliana in relation to that of E. cloeziana can be observed. This result was pronounced, since E. cloeziana wood was naturally resistant to the fungus tested. This is probably associated with the quantity and type of extractive in this wood, as reported by Paes et al. (2016).

\section{DISCUSSION}

The variation of retention among saline solutions can be considered homogeneous $\left( \pm 3 \mathrm{~kg} \mathrm{~m}^{-3}\right)$, Table 1 , and so little influence on the consumption of treated wood by the fungus tested. The result is associated with the efficiency of the salt and natural resistance of the tested wood.

With the base on the values contained in Table 2, the all salt solutions improve the C. torelliana wood resistance to deterioration caused by Postia placenta fungus. This was pronounced, primarily by biological resistance of the E. cloeziana to the Postia placenta that was higher than $21.87 \%$ when compared to the $C$. torelliana. The average value of biological resistance of wood C. toreliana to Postia placenta brown rot fungus was within the range observed for Lopez et al (2018) for the round wood with diameter of 10 to 12; and 12 to 14 $\mathrm{cm}$, that ranged from 22.56 a $26.51 \%$, respectively, the authors classified the wood as moderate resistance, on the basis of the ASTM D-2017 (2008).

For Corymbia torelliana wood, the non-impregnated samples showed a deterioration of $84.85 \%$ caused by the fungus in relation to the impregnated ones, with magnesium sulfate proportionally providing the lowest mass loss for the wood of this species. Thus, all the saline solutions tested had potential to be indicated in the impregnation of the wood minimizing the deterioration caused by the attack of the brown rot fungus tested, being one of the fungi responsible for large losses of wood exposed in direct contact with the soil or in humid conditions that propitiate its attack. However, it is still needed assays to evaluate the lixiviation, effectiveness in field conditions and environmental pollution problem, caused by possible leaching or metal corrosion caused by salts.

It is observed, in general, that the Eucalyptus cloeziana wood presented the smallest mass loss caused by the degradation of the Postia placenta fungus, both for the non-treated samples and for the other salts used. Although not detected statistical differences between the means for the treated and untreated samples, for some salts the deterioration caused in the wood was more than double that observed for the untreated one. This may be related to chemical reactions with wood that promoted the removal of some constituents responsible for the inhibition of the growth of tested fungus. Even so, the efficiency of some salts, such as magnesium and zinc sulfates, was observed in improving wood resistance, reaching values of $63.43 \%$ (zinc sulfate) in relation to the untreated wood.

In the literature, the use of fungi causing brown rot in the deterioration of the wood, Postia placenta being one of them, there are divergences between the results obtained by several authors for the different woods analyzed 
(BRITO et al., 2008; ANDRADE et al. 2012; LOPES et al., 2018). The divergences in the results may be related to the force of fungus strain used, regions of the trunk, age and growth sites for the evaluated woods.

This is in accordance with the observation of Hill (2006), that in natural system of interaction between biological materials (fungus and wood); there will always be variability in results and even contradictory, unexpected and inexplicable results. Paes (2002) demonstrated such a relationship when evaluating the natural resistance of wood of the genus Corymbia to xylophagous fungi, obtaining mass loss values from 5.12 to $20.62 \%$, depending on the region evaluated in pith-bark direction into tree trunk.

Another explanation would be the type of wood exposed to the degradation, as well as the extractive content present in the wood, since the wood has high variability of its constituents both in the base-top and in the pith-bark directions. The fungi initially consume the sapwood and later, after the loss of some extracts of the heartwood caused by evaporation, leaching and reactions caused by the environment, they initiate the heartwood attack. According to Rayner; Boddy, (1995) the attacks of xylophagous organisms are associated with the class, quantity and location of the extractives in the wood.

For the same woods used in the present work, Paes et al. (2016) obtained values of extractives soluble in ethanol: toluene (2: $1 \mathrm{v} / \mathrm{v})$ of 4.65 and $5.40 \%$ for $C$. torelliana and E. cloeziana, respectively. The lower amount of extractives may have favored deterioration caused by the tested fungus on $C$. torelliana wood.

The fungi usually have a greater capacity for deterioration of sapwood, since there are phenolic substances with fungicidal properties and insecticides in the heartwood. However, the extractives do not distribute homogeneously in the stem, presenting their highest concentration and, consequently, the greater natural resistance in the wood of the external parts of the heartwood and near the base of the tree. In the case of sapwood, the natural resistance is lower (MELO et al., 2010; SILVA et al., 2014, COSTA et al., 2017).

The use of saline solutions provided a beneficial effect on the resistance of $C$. torelliana wood to the deterioration caused by the Postia placenta fungus. This improvement may be related to the fungicidal and antibacterial effects of sodium compounds, copper, zinc and magnesium sulfates and lithium chloride. In some of them, such as copper and zinc compounds, they are part of formulations used for the protection of wood against the action of decay fungi and xylophagous insects. It is interesting for new research with these substances in order to provide improvements in the resistance of the wood of other forest species, especially those coming from the Eucalyptus and Pinus genus to expand their uses in the country's forest-based industries.

\section{CONCLUSIONS}

- The untreated Eucalyptus cloeziana wood obtained less mass loss than that of the untreated Corymbia torreliana, when submitted to fungus attack.

- The impregnation with the salts promoted improvements in the biological resistance of the wood of Corymbia torreliana, making it more resistant to the tested fungus.

- The Eucalyptus cloeziana wood impregnated with sodium chloride, lithium chloride and sodium carbonate had deterioration caused by fungus Postia placenta more than double that observed for the untreated wood.

\section{REFERENCES}

AMERICAN SOCIETY FOR TESTING AND MATERIALS ASTM D-2017: standard method for accelerated laboratory test of natural decay resistance for woods. Annual Book of ASTM Standard, West Conshohocken, 2008. $5 \mathrm{p}$.

AMERICAN SOCIETY FOR TESTING AND MATERIALS. ASTM D-1413: standard test method for wood preservatives by laboratory soil-block cultures. Annual Book of ASTM Standard, West Conshohocken, 2008. 8 p.

ANDRADE, F. A.; CALONEGO, F. W.; SEVERO, E. T. D.; FURTADO, E.L. Selection of fungi for accelerated decay in stumps of Eucalyptus spp. Bioresource Technology, v. 110, p. 456-461, 2012.

ARAUJO, J. B. S.; PAES, J. B. natural wood resistance of Mimosa caesalpiniifolia in field testing. Floresta e Ambiente, Seropédica, v. 25, n. 2, p. e20150128, 2018.

BRITO, J. O.; SILVA, F. G.; LEÃO, M. M.; ALMEIDA, G. Chemical composition changes in Eucalyptus and Pinus woods submitted to heat treatment. Bioresource Technology, v. 99, p. 8545-8548, 2008.

COSTA, L. G.; PAES, J. B.; JESUS JUNIOR, W. C.; BROCCO, V. F.; FURTADO, E. L. Potential of selected fungi for biological stump removal of Eucalyptus spp. Forest Ecology and Management, v. 402, p. 265-271, 2017.

FLORESTA, Curitiba, PR, v. 50, n. 2, p. 1373 - 1378, abr/jun 2020. 
HILL, C. Wood modification: chemical, thermal and other processes. West Sussex: John Wiley \& Sons, 2006. $260 \mathrm{p}$.

LOPES, D. J. V.; PAES, J. B.; BOBADILHA, G. S. Resistance of Eucalyptus and Corymbia treated woods against three fungal species. Bioresouces, Raleigh, v. 13, n. 3, p. 4964-4972, 2018.

MARCHESAN, R.; LOIOLA, P. L.; TECCHIO, M. M.; JUIZO, C. G. F.; ROCHA, M. P.; KLITZKE, R. J. Avaliação de técnicas de anelamento e inserção de sabre de motosserra em árvores de Eucalyptus grandis visando maior qualidade da madeira serrada. Floresta, Curitiba, v. 45, p. 695-704, 2015.

MELO, R. R.; STANGERLIN, D. M.; SANTINI, E. J.; HASELEIN, C. R.; GATTO, D. A.; SUSIN, F. Durabilidade natural da madeira de três espécies florestais em ensaios de campo. Ciência Florestal, Santa Maria, V. 20, n. 2, p. 357-365, 2010.

PAES, J. B. Resistência natural da madeira de Corymbia maculata (Hook.) K.D.Hill \& L.A.S. Johnson a fungos e cupins xilófagos, em condições de laboratório. Revista Árvore, Viçosa, v.26, n.6, p.761-767, 2002.

PAES, J. B.; GUERRA, S. C. S.; SILVA, L. F.; OLIVEIRA, J. G. L.; SÃO TEAGO, G. B. Efeito do teor de extrativos na resistência natural de cinco madeiras ao ataque de cupins xilófagos. Ciência Florestal, Santa Maria, v. 26, n. 4, p. 1259-1269, 2016.

PAES, J. B.; LOIOLA, P. L.; BRAZ, R. L.; KLITZKE, R. J.; TIBURTINO, R. F. Corrosividade causada por soluções salinas empregadas na estabilização dimensional da madeira. Floresta e Ambiente, Seropédica, v. 24, p. e00026613, 2017.

PAES, J. B.; LOIOLA, P. L.; EUFLOSINO, A. E. R.; SALVADOR, F. M.; VITORIA, J. B. Efeito de soluções salinas na estabilidade dimensional da madeira de kiri (Paulownia tomentosa). Revista Científica Eletrônica de Engenharia Florestal, v. 21, n.1, p. 72-84, 2013.

PAES, J. B.; LOIOLA, P. L.; OLIVEIRA, J. T. S.; BRAZ, R. L.; KLITZKE, R. J. Efeito de soluções salinas na estabilidade dimensional das madeiras de Corymbia tolleriana e Eucalyptus cloeziana. Scientia Forestalis, Piracicaba, v. 43, p. 105-125, 2015.

PAES, J. B.; MELO, R. R.; LIMA, C. R.; GUEDES, R. S. Eficiência do tratamento preservativo na resistência da madeira de leucena (Leucaena leucocephala (Lam.) de Wit.) a organismos xilófagos. Revista Forestal Venezolana, Mérida, v. 52, n. 1, p. 85-91, 2008.

RAYNER, A. D. M.; BODDY, L. Fungal decomposition of wood: its biology and ecology. Chichester: John Wiley \& Sons, 1995. 587 p.

RINGMAN, R.; PILGÅRD, A.; KÖLLE, M.; BRISCHKE, C.; RICHTER, K. Effects of thermal modification on Postia placenta wood degradation dynamics: measurements of mass loss, structural integrity and gene expression. Wood Science and Technology, v. 50. n. 2, p. 385-397, 2015.

SILVA, L. F.; PAES, J. B.; JESUS JUNIOR, W. C.; OLIVEIRA, J. T. S.; FURTADO, E. L., ALVES, F. R. Deterioração da madeira de Eucalyptus spp. por fungos xilófagos. Cerne, Lavras, v. 20 n. 3, p. 393-400, 2014.

SIAU, J. F. Wood: influence of moisture on physical properties. Virginia: Polytech. Inst. Dep. of Wood Science and Forest Product, 1995. 227p.

STEEL, R. G. D.; TORRIE, J. H. Principles and procedures of statistic: a biometrical approach. 2. ed. New York: Mc Graw Hill, 1980. 633 p. 